\title{
Sodium/Nucleoside Cotransporter 1
}

National Cancer Institute

\section{Source}

National Cancer Institute. Sodium/Nucleoside Cotransporter 1. NCI Thesaurus. Code C96051.

Sodium/nucleoside cotransporter 1 ( $649 \mathrm{aa}, \sim 72 \mathrm{kDa}$ ) is encoded by the human SLC28A1 gene. This protein is involved in sodium-mediated transport of nucleotides. 